\title{
Analisis Permintaan Beras di Kota Padang Sumatera Barat:Pendekatan Ordinary Least Squares
}

\section{Demand Analysis of Rice in Padang West Sumatera : Ordinary Least Squares Approach}

\author{
Angelia Leovita ${ }^{1}$ dan Dian Fauzi ${ }^{2}$ \\ 1,2Program Studi Agribisnis, Fakultas Pertanian, Universitas Tamansiswa Padang \\ Jl. Tamansiswa No.9, Alai Parak Kopi, Padang Utara, Sumatera Barat 25171 \\ Email : angelialeovita41@gmail.com
}

Diterima : 5 September 2018 Revisi : 6 Oktober 2018 Disetujui : 19 November 2018

\begin{abstract}
ABSTRAK
Beras merupakan makanan pokok bagi mayoritas penduduk Indonesia. Negara harus dapat menjamin ketahanan pangan bagi penduduknya dengan ketersediaan dan kemudahan untuk diakses sepanjang tahun. Penelitian ini bertujuan untuk menganalisis faktor-faktor yang mempengaruhi permintaan beras. Jenis penelitian yang digunakan adalah dengan metode pendekatan kuadrat terkecil atau OLS (Ordinary Least Squares) dan alat analisis yang digunakan adalah regresi linear berganda. Hasil uji $F$ menunjukkan bahwa variabel harga beras, harga jagung dan jumlah penduduk secara simultan berpengaruh terhadap permintaan beras. Berdasarkan uji t, variabel harga beras dan jumlah penduduk berpengaruh positif dan signifikan sedangkan variabel harga jagung berpengaruh positif dan tidak signifikan.

kata kunci: beras, permintaan
\end{abstract}

\section{ABSTRACT}

Rice is one of the most important staple food for Indonesian people. Indonesian Government must ensure to guarantee that rice is available and accessible throughout the year. This study aimed to analyze the factors that influence rice demand. The research method applied with the least squares approach or OLS (Ordinary Least Squares) and the analysis tool used was multiple linear regression. The results of the F-test showed that the variable price of rice, the price of corn, and the number of population affected the demand for rice. Based on the t-test, the variable price of rice and the number of the population had a positive and significant effect, while the variable price of corn had a positive and insignificant effect.

keywords: rice, price, number of population, demand

\section{PENDAHULUAN}

umlah penduduk mencapai 255,46 juta. Tingkat konsumsi beras masyarakat Indonesia mencapai 124,89 $\mathrm{kg} / \mathrm{kapita}$ tahun. Artinya bahwa Indonesia memerlukan pangan yang cukup besar, oleh karena itu peningkatan beras harusnya menjadi prioritas utama dalam mengatasi kekurangan permintaan beras (Pusat Data dan Sistem Informasi Pertanian, 2016).
Beras memegang peranan penting dalam kehidupan ekonomi Indonesia. Situasi beras secara tidak langsung dapat mempengaruhi situasi bahan makanan lainnya. Misalkan jika harga beras mengalami kenaikan di pasaran, maka harga barang konsumsi lainnya cenderung ikut mengalami kenaikan.

Pada tahun 2016-2019 besaran angka konsumsi perkapita beras adalah sebesar $124,89 \mathrm{~kg} / \mathrm{kapita} / \mathrm{tahun}$ dengan besaran

Analisis Permintaan Beras di Kota Padang Sumatera Barat: Pendekatan Ordinary Least Squares Angelia Leovita dan Dian Fauzi 
konsumsi beras di tingkat rumah tangga antara 97,91 kg/kapita/tahun hingga 98,01 $\mathrm{kg} / \mathrm{kapita} / \mathrm{tahun}$. Proyeksi permintaan beras tahun 2016 hingga 2019 diperkirakan akan naik sebesar 1,20 persen per tahun atau permintaan beras diperkirakan mencapai ratarata 32,90 juta ton atau mencapai 32,31 juta ton di tahun 2016 dan diperkirakan akan mencapai 33,47 juta ton di tahun 2019 (Tabel 1)

Tabel 1. Hasil Proyeksi Permintaan Beras di Indonesia Tahun 2012-2019

\begin{tabular}{ccc}
\hline Tahun & $\begin{array}{c}\text { Jumlah } \\
\text { Penduduk } \\
\text { (000 orang) }\end{array}$ & $\begin{array}{c}\text { Proyeksi } \\
\text { Permintaan } \\
\text { Beras (ton) }\end{array}$ \\
\hline 2011 & 241.991 & 32.179 .923 \\
2012 & 245.425 & 32.636 .643 \\
2013 & 248.818 & 32.087 .831 \\
2014 & 252.165 & 33.532 .875 \\
2015 & 255.462 & 31.904 .612 \\
2016 & 258.705 & 32.309 .667 \\
2017 & 261.891 & 32.707 .555 \\
2018 & 265.015 & 33.097 .761 \\
2019 & 267.974 & 33.467 .298 \\
Rata- & 263.396 & 32.895 .570 \\
rata & & \\
\hline
\end{tabular}

Sumber : Pusdatin (2016)

Beras merupakan komoditas bahan pangan pertanian utama di Kota Padang. Penduduk Kota Padang mengkonsumsi beras sebagai makanan pangan utama. Kota padang merupakan kota yang sampai saat ini pertaniannya masih ada. Lahan pertanian pangan yang terdapat di wilayah perkotaan wajib dilindungi sebagai lahan pertanian berkelanjutan.

Kota Padang merupakan kota yang pertaniannya masih terjaga. Lahan pertanian pangan di wilayah kota wajib dilindungi sebagai lahan pertanian berkelanjutan. Perlindungan lahan pertanian melalui UndangUndang No.41 tahun 2009 dilakukan dengan mengidentifikasi lahan pertanian yang ada, baik yang beririgrasi teknis maupun tidak beririgrasi, serta lahan potensial untuk produksi pertanian.

Tahun 2014-2016 luas panen, produksi dan produktivitas mengalami naik turun (Tabel 2). Pada tahun 2015 luas panen meningkat dari tahun sebelumnya dan menurun pada tahun 2016, produksi menurun sebesar 1.311 ton pada tahun 2015 dan kembali meningkat sebesar 1.892 ton pada tahun 2016 dan untuk produktivitas tahun 2014 adalah sebesar 5,44 $\mathrm{kuintal} / \mathrm{ha}$, mengalami penurunan pada tahun 2015 menjadi 4,98 kuintal/ha dan meningkat menjadi 5,46 kuintal/ha. Penurunan jumlah produksi dapat disebabkan oleh banyak faktor, seperti terjadinya bencana alam, gagal panen,

Tabel 2. Perkembangan Luas Panen, Produksi dan Produktivitas Padi di Kota Padang Tahun 20142016

\begin{tabular}{rcc}
\hline Tahun & $\begin{array}{c}\text { Luas } \\
\text { Panen } \\
\mathbf{( H a )}\end{array}$ & $\begin{array}{c}\text { Produksi } \\
\text { (Ton) }\end{array}$ \\
\hline 2014 & 16.529 & 90.064 \\
2015 & 17.838 & 88.753 \\
2016 & 16.594 & 90.645 \\
\hline Sumber & $:$ (Badan & Pusat Statistik Kota \\
\multicolumn{4}{|c}{ Padang, 2017) }
\end{tabular}

hama dan penyakit.

Ketersediaan beras di Sumatera Barat tahun 2014 adalah 1.439.127 ton dengan kebutuhan 539.652 ton. Dalam hal ini terjadi surplus beras sebesar 899.474 ton. Sedangkan untuk Kota Padang pada tahun 2014 produksi beras sebesar 43.342 ton dengan kebutuhan 93.547 ton (Badan Ketahanan Pangan Sumbar, 2014). Terjadi kekurangan atau minus beras sebesar 51.363 ton. Permasalahan muncul ketika terjadi kesenjangan antara ketersediaan dengan kebutuhan beras. Dalam sejarahnya Indonesia pernah mengalami swasembada beras, artinya pemenuhan kebutuhan masyarakat Indonesia akan beras terpenuhi karena produksi dalam negeri. Namun saat ini, Indonesia menjadi negara pengimpor beras. $\mathrm{Hal}$ ini terjadi karena peningkatan jumlah penduduk yang berdampak pada peningkatan kebutuhan akan beras tidak dibarengi dengan peningkatan produksi beras. Dengan demikian kebutuhan lebih besar dibandingkan dengan ketersediaan beras yang ada.

Kota Padang sendiri dalam pemenuhan kebutuhan akan beras, beras diambil dari daerah produksi padi lainnya sehingga kebutuhan masyarakat akan beras terpenuhi. 
Permasalahan muncul ketika terjadi kesenjangan antara ketersediaan dengan kebutuhan beras. Dari uraian diatas bahwa permintaaan/kebutuhan beras yang tinggi namun tidak didukung oleh pasokan beras yang mumpuni. Maka dari persoalan diatas mendorong penulis untuk menganalisis faktor yang menjadi pengaruh permintaan beras di Kota Padang.

\section{METODOLOGI}

\subsection{Metode Dasar Penelitian}

Metode deskriptif digunakan dalam penelitian ini. Data yang digunakan adalah data time series dari tahun 2004 sampai tahun 2016 yang meliputi data permintaan beras, harga beras, harga jagung dan jumlah penduduk.

\subsection{Lokasi penelitian}

Lokasi penelitian diambil dengan purposive. Lokasi penelitian yang dipilih adalah Kota Padang dengan pertimbangan bahwa Kota Padang merupakan daerah sentral produksi padi di Sumatera Barat.

\subsection{Jenis dan Sumber Data}

Data yang digunakan data sekunder yang diperoleh melalui instansi atau lembagalembaga yang terkait dengan kegiatan penelitian ini, seperti: Badan Pusat Statistik (BPS) Kota Padang dan instansi lainnya yang berhubungan dengan penelitian ini.

\subsection{Metode Analisis Data}

Hubungan antara permintaan beras dengan faktor-faktor yang mempengaruhinya dianalisis dengan analisis linear berganda dengan model perpangkatan atau eksponensial. Secara matematis model yang digunakan adalah sebagai berikut:

$Q d=b_{0}+b_{1} X_{1}+b_{2} X_{2}+b_{3} X_{3}+e$

Keterangan :

Qd = Jumlah Permintaan beras

b0 = Konstanta

$\mathrm{X} 1=$ Harga beras $(\mathrm{Rp} / \mathrm{kg})$

$\mathrm{X} 2=$ Harga jagung $(\mathrm{Rp} / \mathrm{kg})$

X3 =Jumlah penduduk (jiwa)

Uji $\bar{R}^{2}$ (adjusted $\left(\bar{R}^{2}\right)$ untuk mengetahui besarnya pengaruh variabel bebas terhadap permintaan beras di kota Padang. Semakin besar $\bar{R}^{2}$ (mendekati 1) semakin baik hasil regresi tersebut dan semakin mendekati 0 maka variabel bebas secara keseluruhan semakin kurang dapat menjelaskan variabel tidak bebas. Uji simultan atau uji $F$ untuk mengetahui apakah variabel bebas $(X)$ secara bersama-sama mempengaruhi variabel terikat (Y). Uji t bertujuan untuk mengetahui apakah variabel bebas (variabel $X$ ) secara parsial berpengaruh signifikan terhadap variabel terikat (variabel Y).

Gejala multikolinieritas diuji dengan menggunakan metode variance inflaction factor (VIF), tolerance (TOL) dan matrik korelasi (Pearson Correlation Matrix). Pengujian multikolinearitas dilihat dari besaran VIF (Variance Inflation Factor) dan tolerance. Multikolinearitas terjadi jika nilai tolerance $\leq$ 0,01 atau sama dengan nilai VIF $\geq 10$ (Priyatno, 2011).

Heteroskedastisitas diuji dengan Uji Glejser. Jika nilai signifikansi antara variabel independen dengan absolut residual lebih dari 0,05 maka tidak terjadi masalah heteroskedastisitas.

Dengan uji Run Test dapat dilakukan pengujian ada tidaknya autokorelasi. Jika nilai signifikan kecil dari 0,05 maka terjadi autokorelasi dan jika nilai besar 0,05 maka tidak terjadi autokorelasi. Uji ini untuk melihat apakah data terdistribusi normal atau tidak. Uji dilakukan atau dianalisis dengan KolmogorovSmirnov Test, dengan membandingkan asymptotic significance dengan $\alpha=0,05$. Dasar penarikan kesimpulan adalah data dikatakan berdistribusi normal apabila asymptotic significance lebih besar dari 0,050.

\section{HASIL DAN PEMBAHASAN}

\subsection{Pengujian Model}

Sebelum dilakukan analisis regresi linear berganda pada model, terlebih dahulu dilakukan pengujian-pengujian pada model yang telah dibentuk. Uji Asumsi Klasik adalah syarat-syarat yang harus dipenuhi pada model regresi linear OLS agar model menjadi valid sebagai alat penduga. Uji asumsi klasik pada regresi linear berganda antara lain: (i) 
Multikolinearitas; (ii) Heteroskedastisitas; (iii) Autokorelasi; dan (iv) Normalitas.

Berdasarkan hasil pengolahan data yang terdapat pada Tabel 3, diketahui bahwa nilai Uji $\bar{R}^{2}$ (adjusted $\left(\bar{R}^{2}\right)$ adalah sebesar 0,972 . Hal ini menunjukkan bahwa besarnya pengaruh variabel-variabel bebas terhadap permintaan beras di Kota Padang adalah sebesar 97,20

Tabel 3. Uji $\bar{R}^{2}$ (adjusted $\left(\bar{R}^{2}\right)$

\begin{tabular}{llll}
\hline $\begin{array}{l}\text { Mode } \\
\mathbf{I}\end{array}$ & $\mathbf{R}$ & R Square & $\begin{array}{l}\text { Adjusted } \\
\text { R Square }\end{array}$ \\
\hline 1 & $0,989^{\mathrm{a}}$ & 0,979 & 0,972 \\
\hline
\end{tabular}

persen, variabel tersebut adalah variabel harga beras, variabel harga jagung dan variabel jumlah penduduk. Sisanya 2,8 persen dipengaruhi oleh variabel lain yang tidak dimasukkan dalam model.

Berdasarkan uji $\mathrm{F}$ yang terdapat pada Tabel 4, diketahui nilai signifikansi untuk pengaruh $X 1, X 2$ dan $X 3$ secara simultan terhadap $Y$ adalah sebesar 0,000 dan nilai $F$ hitung 137,695. Ketentuan dalam pengambilan keputusan: (i) Jika nilai signifikansi $<0,05$ atau $F$ hitung $>F$ tabel maka terdapat pengaruh variabel $X$ secara simultan terhadap variabel Y; (ii) Jika nilai signifikansi

Tabel 4. Uji F

\begin{tabular}{lrrr}
\hline & $\begin{array}{c}\text { Regressi } \\
\text { on }\end{array}$ & Residual & Total \\
\hline Sum of & $1,461 \mathrm{E} 14$ & $3,183 \mathrm{E} 12$ & $1,493 \mathrm{E} 14$ \\
Squares & & & \\
\hline Df & 3 & 9 & 12 \\
\hline Mean & $4,870 \mathrm{E} 13$ & $3,537 \mathrm{E} 11$ & \\
Squares & & & \\
\hline $\mathrm{F}$ & 137,695 & & \\
\hline Sig & $0,000^{\mathrm{a}}$ & & \\
\hline
\end{tabular}

$>0,05$ atau $\mathrm{t}$ hitung $<\mathrm{F}$ tabel maka tidak terdapat pengaruh variabel $X$ secara simultan terhadap variabel $\mathrm{Y}$. Hasil uji $\mathrm{F}$ atau uji simultan dalam penelitian ini menunjukkan bahwa nilai signifikansi yaitu $0,000<0,05$ atau nilai $F$ hitung 137,695> $F$ tabel $(3,98)$, sehingga terdapat pengaruh $\mathrm{X} 1, \mathrm{X} 2$ dan $\mathrm{X} 3$ secara simultan terhadap $Y$. Artinya secara bersama-sama variabel harga beras, variabel harga jagung dan jumlah penduduk mempengaruhi permintaan beras di Kota Padang.

Ketentuan dalam pengambilan keputusan dalam uji t adalah : (i) Jika nilai signifikansi< 0,05 atau $t$ hitung $>t$ tabel maka terdapat pengaruh variabel $X$ terhadap variabel $Y$; (ii) Jika nilai signifikansi $>0,05$ atau $t$ hitung $<\mathrm{t}$ tabel maka tidak terdapat pengaruh variabel $X$ terhadap variabel $\mathrm{Y}$. Berdasarkan Tabel 5 didapatkan hasil uji $\mathrm{T}$ adalah : (i) Nilai signifikansi untuk variabel $\mathrm{X} 1$ sebesar $0,01<$ 0,05 dan nilai t hitung 4,957 > dari t tabel $(2,262)$. Hal ini berarti terdapat pengaruh variabel $\mathrm{X} 1$ terhadap variabel $\mathrm{Y}$, sehingga dapat disimpulkan harga beras secara signifikan mempengaruhi permintaan beras di Kota Padang; (ii) Nilai signifikansi variabel X2 adalah $0,911>0,05$ dan nilai thitung $0,115<\mathrm{t}$ tabel $(2,262)$. Hal ini berarti tidak terdapat pengaruh variabel $\mathrm{X} 2$ terhadap variabel $\mathrm{Y}$, sehingga dapat disimpulkan bahwa harga jagung tidak mempengaruhi secara signifikan permintaan beras di Kota Padang; (iii) Nilai signifikansi variabel $\mathrm{X} 3$ diketahui adalah sebesar 0,039<0,05 dan nilai t hitung 2,422 > $\mathrm{t}$ tabel (2,262), maka terdapat pengaruh variabel $\mathrm{X} 3$ terhadap variabel $\mathrm{Y}$, dan dapat disimpulkan bahwa jumlah penduduk secara signifikan mempengaruhi permintaan beras di Kota Padang.

Uji multikolinearitas merupakan prasyarat yang harus terpenuhi dalam model regresi. Multikolinearitas diuji dengan menggunakan metode variance inflaction

Tabel 5. Uji t

\begin{tabular}{lcccc}
\hline \multicolumn{1}{c}{ Model } & Constant & X1 & X2 & X3 \\
\hline Unstandardized coefficients & & & & \\
- B & $2,995 \mathrm{E} 7$ & 813,888 & 23,772 & 27,483 \\
- Std. Error & $8,661 \mathrm{E} 6$ & 164,181 & 206,382 & 206,382 \\
Standardized coefficients Beta & & 0,699 & 0,013 & 0,297 \\
t & 3,458 & 4,957 & 0,115 & 2,422 \\
Sig & 0,007 & 0,001 & 0,911 & 0,039 \\
\hline
\end{tabular}

Analisis Permintaan Beras di Kota Padang Sumatera Barat: Pendekatan Ordinary Least Squares Angelia Leovita dan Dian Fauzi 
Tabel 6. Uji Multikolinearitas Metode Variance Inflaction Factor (VIF)

\begin{tabular}{lllll}
\hline Model & Constant & X1 & X2 & X3 \\
\hline Unstandardized Coefficients & & & & \\
- B & $2,995 \mathrm{E} 7$ & 813,888 & 23,772 & 27,483 \\
- Std.Error & $6,661 \mathrm{E} 6$ & 164,181 & 206,382 & 11,349 \\
Unstandardized Coefficients Beta & & 0,699 & 0,013 & 0,297 \\
T & 3,458 & 4,957 & 0,115 & 2,422 \\
Sig & 0,007 & 0,001 & 0,911 & 0,039 \\
Collinearity Statistics & & & & \\
- Tolerance & & 0,119 & 0,180 & 0,158 \\
- VIF & & 8,389 & 5,552 & 6,344 \\
\hline
\end{tabular}

factor (VIF), tolerance (TOL) dan matrik korelasi (Pearson Correlation Matrix). Berdasarkan Tabel 6 dapat dijabarkan bahwa nilai VIF dari variabel penelitian $<10$ dan mempunyai tingkat tolerance $>0,01$ sehingga tidak terdapat Mutikolinearitas.

Uji heteroskedastisitas dilakukan dengan Uji Glejser. Jika nilai signifikansi > 0,05 maka tidak terjadi masalah heterokedastisitas. Pada Tabel 7 didapatkan nilai signifikansi pada harga beras adalah sebesar 0,313 , nilai signifikansi pada variabel harga jagung adalah 0,887 dan nilai signifikansi pada variabel jumlah penduduk adalah sebesar 0,086 memiliki nilai > 0,05, maka tidak terjadi heteroskedastisitas. Apabila asumsi heteroskedastisitas tidak terpenuhi maka model regresi dinyatakan tidak valid. lebih besar dari 0,05 dapat disimpulkan bahwa residual random atau tidak terjadi autokorelasi antar nilai residual.

Berdasarkan Tabel 8 dapat dilihat nilai Asymp. Sig. (2-tailed) pada hasil Uji autokorelasi dengan Run Tes adalah sebesar 0,982 , nilai ini $>0,05$, maka tidak terjadi autokorelasi.

Tabel 8. Uji Autokorelasi Run Test

\begin{tabular}{lr}
\hline Model & $\begin{array}{l}\text { Unstandardized } \\
\text { Residual }\end{array}$ \\
\hline Test Value & $-2,13231 \mathrm{E} 5$ \\
Cases $<$ Test Value & 6 \\
Cases $>=$ Test Value & 7 \\
Total Cases & 13 \\
Number of Runs & 8 \\
Z & 0,022 \\
Asymp. Sig. (2-tailed) & 0,982 \\
\hline
\end{tabular}

Tabel 7. Uji Heterokedastisitas

\begin{tabular}{lrrrr}
\hline Model & Constant & X1 & X2 & \multicolumn{1}{c}{ X3 } \\
\hline Untandardized & & & & \\
Coefficients & & & & \\
- B & $3,917 \mathrm{E} 6$ & 87,937 & 15,086 & $-5,032$ \\
- Std. Error & $4,344 \mathrm{E} 6$ & 82,338 & 103,502 & 5,692 \\
Standardized Coefficients & & & & \\
Beta & & 0,906 & 0,101 & $-0,652$ \\
t & 0,902 & 1,064 & 0,146 & $-0,884$ \\
Sig & 0,391 & 0,313 & 0,887 & 0,400 \\
\hline
\end{tabular}

Autokorelasi dapat dideteksi dengan menggunakan Run Test. Pengambilan keputusan pada uji Run Test adalah sebagai berikut: (i) Jika hasil uji Run Test menunjukkan nilai signifikan lebih kecil dari 0,05 maka dapat disimpulkan bahwa residual tidak random atau terjadi autokorelasi antar nilai residual; (ii) Jika hasil uji Run Test menunjukkan nilai signifikan
Uji normalitas dianalisis dengan Kolmogorov-Smirnov Test. Terjadi distribusi normal jika nilai asymptotic significance > 0,050 . Pada Tabel 9 dapat dilihat bahwa nilai Asymp. Sig. (2-tailed) adalah sebesar 0,647. $>0,050$ sehingga data terdistribusi normal. 
Tabel 9. Uji Normalitas Data Kolmogorov- Smirnov Test

\begin{tabular}{ccc}
\hline Model & & $\begin{array}{c}\text { Unstandardized } \\
\text { Residual }\end{array}$ \\
\hline $\mathrm{N}$ & Mean & 13 \\
Norma Parameters & & 0,0000000 \\
& Std.Deviation & $5,15017385 \mathrm{E} 5$ \\
Most Extreme Differences & Absolute & 0,205 \\
& Positive & 0,205 \\
Kolmogrov-Smirnov $Z$ & Negative & $-0,115$ \\
Asymp. Sig. (2-tailed) & & 0,738 \\
\hline
\end{tabular}

\subsection{Analisi Regresi Berganda}

Hasil perhitungan analisis regresi linear berganda dalam penelitian ini dapat dilihat pada Tabel 10 dan Tabel 11.

Tabel 10. Hasil Regresi Linear Berganda

\begin{tabular}{lll}
\hline Model & t & Sig \\
& & \\
\hline 1 (Constant) & 3,458 & 0,007 \\
$\quad$ Harga beras & 4,957 & 0,001 \\
$\quad$ Harga Jagung & 0,115 & 0,911 \\
$\quad$ Jumlah & 2,422 & 0,039 \\
penduduk & & \\
\hline
\end{tabular}

\subsubsection{Variabel Harga Beras}

Berdasarkan uji $t$ diketahui nilai signifikansi variabel harga beras 0,001 . Nilai tersebut lebih kecil dari $<0,05$ artinya variabel harga beras mempunyai pengaruh positif dan signifikan. Nilai harga beras (X1) sebesar 813,888, hal ini menyatakan bahwa setiap kenaikan harga beras sebesar 1 rupiah mengakibatkan permintaan beras akan bertambah sebesar 813,888 kilogram (Tabel 11).

Harga beras terhadap permintaan mempunyai koefisien regresi yang bertanda positif, jika harga beras naik maka permintaan beras akan naik. Hal ini bertentangan dengan teori permintaan. Berdasarkan teori jika harga naik maka permintaan turun dan sebaliknya jika harga turun permintaan naik. Variabel harga beras bertanda positif dapat dijelaskan karena beras merupakan makanan pangan utama masyarakat kota Padang. Barangbarang kebutuhan pokok (atau barang yang tidak memiliki barang pengganti memiliki nilai inelastis $(\mathrm{Ed}<1)$. Artinya konsumen kurang Analisis Permintaan Beras di Kota Padang Sumatera Barat: Pendekatan Ordinary Least Squares Angelia Leovita dan Dian Fauzi perduli terhadap perubahan harga beras, berapa pun kenaikan harga beras masyarakat akan tetap membeli beras meskipun terdapat barang substitusi (dalam penelitian ini adalah jagung).

Variabel beras bertanda positif terhadap permintaan beras juga terdapat dalam penelitian dengan judul "Analisis Faktor-Faktor yang Mempengaruhi Permintaan Beras di Kabupaten Aceh Barat" (Annizami, 2014). Hasil penelitiannya menunjukkan harga beras berpengaruh positif terhadap permintaan beras di Kabupaten Aceh Barat. Nilai harga beras (X2) sebesar 0,129. Hal ini menyatakan bahwa setiap kenaikan harga beras sebesar 1 rupiah mengakibatkan permintaan beras akan bertambah sebesar 0,129 kilogram.

Tabel 11. Regresi Linear Berganda

\begin{tabular}{lccc}
\hline Model & \multicolumn{1}{c}{$\begin{array}{c}\text { Unstandardized } \\
\text { Coefficients }\end{array}$} & $\begin{array}{c}\text { Standar } \\
\text { dized } \\
\text { Coeffici } \\
\text { ents }\end{array}$ \\
\cline { 2 - 4 } & B & Std.Error & Beta \\
\hline $\begin{array}{l}\text { (Constant) } \\
\text { Harga }\end{array}$ & $2,995 \mathrm{E} 7$ & $8,661 \mathrm{E} 6$ & \\
$\begin{array}{l}\text { beras } \\
\text { Harga }\end{array}$ & 813,888 & 164,181 & 0,699 \\
$\begin{array}{l}\text { Jagung } \\
\text { Jumlah } \\
\text { penduduk }\end{array}$ & 23,772 & 206,382 & 0,013 \\
\hline
\end{tabular}

\subsubsection{Variabel Harga Jagung}

Berdasarkan uji $t$ diketahui nilai signifikansi variabel harga jagung 0,911. Nilai tersebut lebih besar dari 0,05 artinya variabel harga jagung tidak mempunyai pengaruh yang signifikan dan berpengaruh positif terhadap 
permintaan beras. Variabel harga jagung bertanda positif terhadap permintaan beras juga terdapat dalam penelitian yang dilakukan Herdiansyah (2016) dengan judul "Analisis Permintaan Beras di Kabupaten Lumajang". Hasil penelitiannya menunjukkan harga jagung bertanda positif terhadap permintaan beras.

Nilai harga jagung (X2) sebesar 23,772 (Tabel 11), hal ini menunjukkan bahwa setiap kenaikan harga jagung sebesar 1 rupiah mengakibatkan permintaan beras akan bertambah sebesar 23,772 kilogram. Jagung dapat dijadikan bahan pangan pengganti alternatif beras. Namun dalam penelitian ini diketahui bahwa jagung tidak berpengaruh terhadap permintaan. Meskipun harga jagung rendah masyarakat tidak beralih ke jagung karena makanan pokok masih beras.

\subsubsection{Variabel Jumlah penduduk}

Berdasarkan uji $t$ diketahui nilai signifikansi variabel jumlah penduduk 0,039. Nilai tersebut lebih kecil dari 0,05 , artinya variabel jumlah penduduk mempunyai pengaruh yang signifikan dan berpengaruh positif terhadap permintaan beras. Nilai jumlah penduduk (X3) sebesar 27,483. Hal ini menunjukkan bahwa setiap kenaikan jumlah penduduk 1 jiwa mengakibatkan permintaan beras akan bertambah sebesar 27.483 kilogram (Tabel 11). Jumlah penduduk mempunyai koefisien regresi yang bertanda positif. Pertambahan jumlah penduduk akan sangat mempengaruhi permintaan beras, apalagi mayoritas makanan pokok masyarakat di Kota Padang adalah beras. Hal ini sejalan dengan penelitian (Mulyowidakda, 2011) yang berjudul "Analisis Permintaan Beras di Kabupaten Klaten".

\section{KESIMPULAN}

Dari tiga variabel yaitu harga beras, harga jagung dan jumlah penduduk yang diduga relevan yang mempengaruhi permintaan beras seluruhnya bertanda positif. Adapun variabel yang memiliki pengaruh yang signifikan adalah harga beras dan jumlah penduduk.
Secara simultan variabel harga beras, harga jagung dan jumlah penduduk berpengaruh terhadap permintaan beras. Harga beras dan jumlah penduduk secara parsial bertanda positif dan berpengaruh. Variabel harga jagung bertanda positif dan tidak berpengaruh signifikan.

\section{DAFTAR PUSTAKA}

Annizami, A. (2014). Analisis Faktor-faktor yang mempengaruhi permintaan beras di kabupaten aceh barat. Teuku Umar. Retrieved from repository.utu.ac.id/403/1/IV.pdf

Badan Ketahanan Pangan Sumbar. (2014). Database ketahanan Pangan Provinsi Sumatera Barat Tahun 2014. Padang. Retrieved from www.sumbarprov.go.id/details/news/6736

Badan Pusat Statistik Kota Padang. (2017). Kota Padang Dalam Angka 2017. PADANG: BPS Kota Padang. Retrieved from https://padangkota.bps.go.id/publication/201 7/08/10/40ffc917a4dc6a6383c24b76/kotapadang-dalam-angka-2017.html

Herdiansyah, A. (2016). Analisis Permintaan Beras Di Kabupaten Lumajang. Artikel IImiah Mahasiswa. Retrieved from repository.unej.ac.id/handle/123456789/7434 4

Mulyowidakda, H. (2011). Analisis Permintaan Beras di Kabupaten Klaten. Sebelas Maret Surakarta. Retrieved from https://eprints.uns.ac.id/6004/1/17999101120 1103421.pdf

Priyatno, D. (2011). Belajar Cepat Olah Data Statistik Dengan SPSS. Yogyakarta: Andi.

Pusat Data dan Sistem Informasi Pertanian. (2016). Outlook Komoditas Pertanian Sub Sektor Tanaman Pangan. Jakarta. Retrieved from epublikasi.pertanian.go.id > Outlook.

\section{BIODATA PENULIS}

Angelia Leovita, dilahirkan di Medan tanggal 09 Agustus 1989. Menyelesaikan pendidikan S1 di Program Studi Agribisnis, Universitas Andalas tahun 2012 dan Pendidikan S2 di Program Studi IImu Ekonomi Pertanian Institut Pertanian Bogor.

Dian Fauzi, dilahirkan di Padang tanggal 22 Oktober 1988. Menyelesaikan pendidikan S1 di Program Studi Agribisnis, Universitas Andalas tahun 2011 dan pendidikan S2 di Departemen Agribisnis, Institut Pertanian Bogor. 
